\title{
Electrochemical Impedance Spectroscopy and Gravimetric Study of the Corrosion Inhibition of API 5L X-52 steel in $\mathrm{HCl}$ Medium by Levofloxacin
}

\author{
Magdalene Edet Ikpi ${ }^{1}$, Fidelis Ebunta Abeng ${ }^{2}$ \\ ${ }^{1,2}$ Corrosion and Electrochemistry Research Laboratory, Department of Pure and Applied Chemistry, \\ University of Calabar, P.M.B. 1115, Calabar-Nigeria
}

\begin{abstract}
Levofloxacin has been tested as corrosion inhibitor for API $5 \mathrm{~L} \mathrm{X-52}$ steel in $2 \mathrm{M} \mathrm{HCl}$ solution using electrochemical impedance spectroscopy (EIS) and gravimetric techniques. The results obtained show an increase in inhibition efficiency and decrease in corrosion rate with increasing concentration of levofloxacin. The kinetic studies of the data followed a first order reaction. The adsorption of the inhibitor was found to be spontaneous and consistent with the assumption of Langmuir adsorption isotherm.
\end{abstract}

Keywords: Levofloxacin, EIS, API 5L X- 52 steel, corrosion inhibition

\section{Introduction}

API 5L X-52 steel is a grade of carbon steel generally used in structural applications as in construction and in metal processing equipment and in industrial applications such as conveying gases, water, oils and natural gas. The application of acid media in the study of the corrosion of carbon steel has become important because hydrochloric and sulphuric acids are the media mostly used for industrial cleaning and acid descaling [1]. The safety of metals against corrosion is the main industrial set back. Thus, the use of corrosion inhibitors is one of the best alternative for protecting metals against corrosion in acid media. Most of the efficient inhibitors used in industry are organic compounds which contain oxygen, nitrogen, sulphur and phosphorus atoms as well as multiple bonds. These compounds function by adsorbing either physically or chemically on the metal surface thereby hindering the corrosion reaction. Though numerous $\mathrm{N}$ heterocyclic organic compounds have good anticorrosive activity, some are highly toxic to humans and the environment. Due to increasing environmental awareness and the adverse effect of some of these chemicals, research activities in recent times are geared towards developing cheap, non-toxic and environmentally safe corrosion inhibitors. Recently, few non-toxic compounds such as farcolin [2], voltaren [3], cefatrexyl [4], dicloxacillin [5], cefixime, [6] erythromycin [7] and ciprofloxacin [8] have been studied as corrosion inhibitors. The present investigation is devoted to evaluate 9-fluoro-2,3-dihydro-3methyl-10-(4-methyl piperazin-1-yl)-7-oxo-7H-pyrido(1,2,3de)-1,4-benzoxazine-6-carboxyclic acid (Levofloxacin) as corrosion inhibitor for API 5L X-52 steel in hydrochloric acid solution using electrochemical impedance spectroscopy and gravimetric techniques.

\section{Experimental}

\subsection{Material preparation}

Tests were performed on API 5L X-52 steel specimens with the following composition (wt \%: (0.24), Mn (1.40), P
(0.05), S (0.015), Si (0.45), V (0.01), Nb (0.05), Ti (0.04) and $\mathrm{Fe}(97.68)$. The specimens were of dimension $1.0 \mathrm{~cm} \times$ $1.0 \mathrm{~cm} \times 1.0 \mathrm{~cm}$ with $6.0 \mathrm{~cm}^{2}$ surface area and these were used for gravimetric measurements. The same size of the steel with $1.0 \mathrm{~cm}^{2}$ exposed surface area isolated with commercially available epoxy resin was used for electrochemical measurements. The API 5L X-52 carbon steel represents the working electrode, which was mechanically ground with 220, 800 and 1200 emery grade paper using a UNIPOL-820 metallographic polishing machine, washed in distilled water, degreased in absolute ethanol and dried in acetone before use.

Levofloxacin (LEVO) was obtained from a pharmaceutical shop in Calabar, Nigeria and was used without further purification. The structure of the studied compound is shown in Figure 1. It has molecular formula of $\mathrm{C}_{18} \mathrm{H}_{20} \mathrm{FN}_{3} \mathrm{O}_{4}$ with molecular mass of $361.373 \mathrm{~g} / \mathrm{mol}$. Different concentrations of the drug was prepared by dissolving appropriate quantities of the tablets from the mass of the drug samples. Together with $\mathrm{HCl}$ of $\mathrm{AR}$ grade and double-distilled water, the inhibitor-acid solution was prepared and the concentration of LEVO in $2 \mathrm{M} \mathrm{HCl}$ varied from $50 \mathrm{ppm}$ to $500 \mathrm{ppm}$.<smiles>C[C@@H]1COc2c(N3CCN(C)CC3)c(F)cc3c(=O)c(C(=O)O)cn1c23</smiles>

Figure 1: Chemical molecular structure of Levofloxacin

\subsection{Electrochemical Impedance Spectroscopy (EIS)}

EIS tests were performed at $303 \mathrm{~K}$ in a three electrode cell using Gamry Reference 600 potentiostat/Galvanostat inclusive of a Gamry framework EIS300 system. Gamry 


\section{International Journal of Science and Research (IJSR) \\ ISSN (Online): 2319-7064}

Index Copernicus Value (2015): 78.96 | Impact Factor (2015): 6.391

Echem Analyst software was used for analyzing and fitting of data. The frequency range was $100 \mathrm{kHz}-0.05 \mathrm{~Hz}$ and an $\mathrm{AC}$ signal amplitude of $5 \mathrm{mV}$ was used. Platinum electrode was used as counter electrode and saturated calomel electrode (SCE) was used as the reference electrodes. Measurements were performed in aerated solution after 30 minutes immersion in the test solution. All potentials were reported versus SCE.

\subsection{Gravimetric Method}

Previously weighed API 5L X-52 steel coupons were completely immersed and suspended with the help of a nylon thread and rods in $250 \mathrm{ml}$ of the test solution of $2 \mathrm{M} \mathrm{HCl}$ alone and with different concentrations of the inhibitors at $(303 \pm 1) \mathrm{K}$. The specimens were retrieved separately after 5 , $10,15,20$ and 25 days of immersion. The corrosion products were removed by washing each coupon in distilled water using a bristle brush. The washed coupons were rinsed in acetone and dried in air before reweighing. The difference in weights for each period of immersion was taken and recorded as the weight loss. From the weight loss results, the inhibition efficiency and the corrosion rate $(C R)$ of API 5L X-52 steel were calculated using the following equations;

$$
\begin{aligned}
& I E=\frac{W L_{0}-W L_{1}}{W L_{0}} \times 100 \\
& C R\left(m m y^{-1}\right)=\frac{87.6 \times W L}{D A T}
\end{aligned}
$$

where $W L_{0}$ is weight loss without inhibitor, $W L_{1}$ is weight loss with inhibitor, $W L$ is weight loss in milligrams, $\mathrm{D}$ is the density of the specimen $\left(7.88 \mathrm{gcm}^{-3}\right), \mathrm{A}$ is surface area of the specimen $\left(\mathrm{cm}^{2}\right)$ and $\mathrm{T}$ is the immersion time (hours).

\section{Results and Discussion}

\subsection{Electrochemical Impedance Spectroscopy (EIS)}

Nyquist plots of API 5L X-52 steel in $2 \mathrm{M} \mathrm{HCl}$ in the absence and presence of various concentrations of Levofloxacin are shown in Figure 2. It is observed that the impedance of API 5L X-52 steel increases with increase in the concentration of inhibitor in $2 \mathrm{M} \mathrm{HCl}$. The diagram shows one capacitive loop corresponding to the charge transfer reaction which is dependent on either electron transfer at the metal surface or on the electron conduction through the surface film [9]. The change in concentration of Levofloxacin did not alter the shape of the impedance behaviour suggesting similar mechanism for the corrosion inhibition of API 5L X-52 steel by Levofloxacin at various concentrations. The symbols in Figure 2 corresponds to the measured data while the solid line represents the fitted data obtained using the equivalent circuit (Figure 3). The impedance parameters obtained from the fit and the calculated inhibition efficiencies are listed in Table 1.

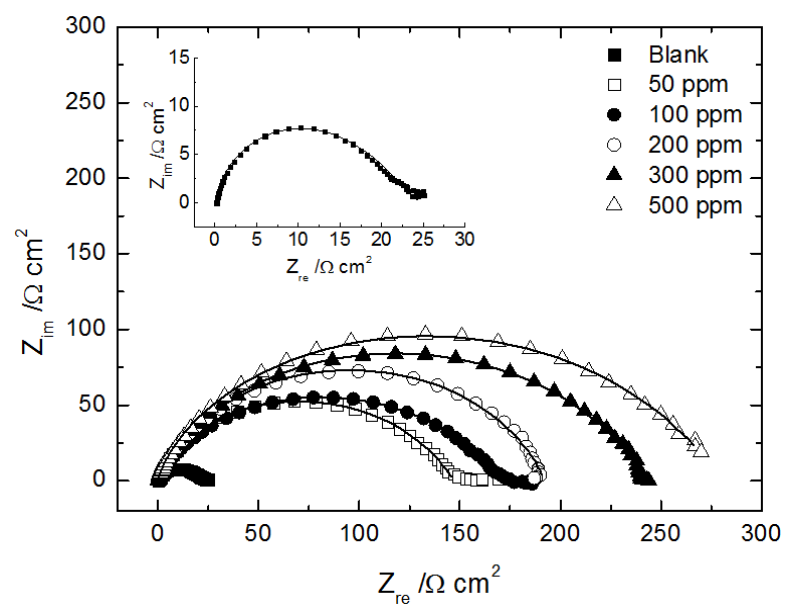

Figure 2: Nyquist plots of API 5L X-52 steel in different concentrations of LEVO in $2 \mathrm{M} \mathrm{HCl}$ (insert is the Nyquist plot obtained in blank solution)

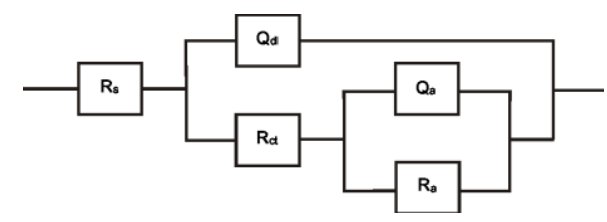

Figure 3: Equivalent circuit model for API 5L X-52 steel in $2 \mathrm{M} \mathrm{HCl}$ solutions in the absence and presence of various concentrations of LEVO

The corrosion inhibition process can be described as both charge-transfer and adsorption controlled. The equivalent circuit model considers the solution resistance $R_{s}$, an adsorption resistance $R_{a}$, an adsorption constant phase element (CPE) $Q_{a}$, a charge-transfer resistance $R_{c t}$ and a constant phase double layer $Q_{d l}$. The constant phase element is a frequency-dependent element that is linked to surface heterogeneities and replaces the double layer capacitor at the metal-electrolyte interface. The impedance of a CPE is given in equation 3 [10];

$$
Z_{C P E}=\left[Y_{0}(j \omega)^{n}\right]^{-1}
$$

where the amplitude $Y_{0}$ is the CPE constant, $j$ the imaginary unit $(j=\sqrt{-1}), \omega$ the angular frequency and $n$ the CPEpower $(0<n \leq 1)$.

The values of $R_{c \mathrm{t}}$ and $R_{a}$ increase with the addition of the inhibitor with the exception for $R_{a}$ at 300 and $500 \mathrm{ppm}$ inhibitor concentration. A corresponding decrease in $Q_{d l}$ and $Q_{a}$ values is also observed for the same concentration range. This decrease is on account of an increase in the thickness of 


\section{International Journal of Science and Research (IJSR) \\ ISSN (Online): 2319-7064}

Index Copernicus Value (2015): 78.96 | Impact Factor (2015): 6.391

Table 1: Electrochemical impedance parameters of API 5L X-52 steel in $2 \mathrm{M} \mathrm{HCl}$ solutions in the absence and presence of different concentration of LEVO.

\begin{tabular}{|c|c|c|c|c|c|c|c|c|}
\hline \multirow[b]{2}{*}{ System } & \multirow[b]{2}{*}{$\begin{array}{c}R_{s} \\
\left(\Omega \mathrm{cm}^{2}\right)\end{array}$} & \multirow[b]{2}{*}{$\begin{array}{c}R_{c t} \\
\left(\Omega \mathrm{cm}^{2}\right)\end{array}$} & \multicolumn{2}{|c|}{$Q_{d l}$} & \multirow[b]{2}{*}{$\begin{array}{c}R_{a} \\
\left(\Omega \mathrm{cm}^{2}\right)\end{array}$} & \multicolumn{2}{|l|}{$Q_{a}$} & \multirow[b]{2}{*}{$\begin{array}{l}I E \\
(\%)\end{array}$} \\
\hline & & & $\begin{array}{c}Y_{0} \\
\left(S s^{n} \mathrm{~cm}^{-2}\right)\end{array}$ & $n_{d l}$ & & $\begin{array}{c}Y_{0} \\
\left(S s^{n} \mathrm{~cm}^{-2}\right)\end{array}$ & $n_{a}$ & \\
\hline $2 \mathrm{M} \mathrm{HCl}$ & 0.23 & 24.29 & $12.00 \times 10^{-4}$ & 0.462 & 0.01 & $20.40 \times 10^{-5}$ & 1.000 & \\
\hline $2 \mathrm{M} \mathrm{HCl}+50 \mathrm{ppm}$ & 0.31 & 144.60 & $3.87 \times 10^{-4}$ & 0.671 & 2.43 & $9.44 \times 10^{-5}$ & 0.999 & 83.2 \\
\hline $2 \mathrm{M} \mathrm{HCl}+100 \mathrm{ppm}$ & 0.29 & 161.40 & $3.30 \times 10^{-4}$ & 0.630 & 9.73 & $7.65 \times 10^{-5}$ & 1.000 & 85.0 \\
\hline $2 \mathrm{M} \mathrm{HCl}+200 \mathrm{ppm}$ & 0.07 & 174.80 & $3.37 \times 10^{-4}$ & 0.746 & 17.38 & $3.20 \times 10^{-5}$ & 1.000 & 86.1 \\
\hline $2 \mathrm{M} \mathrm{HCl}+300 \mathrm{ppm}$ & 0.41 & 227.00 & $1.78 \times 10^{-4}$ & 0.675 & 16.81 & $2.20 \times 10^{-5}$ & 1.000 & 89.3 \\
\hline $2 \mathrm{M} \mathrm{HCl}+500 \mathrm{ppm}$ & 0.10 & 280.40 & $0.73 \times 10^{-4}$ & 1.000 & 0.01 & $44.69 \times 10^{-5}$ & 0.671 & 91.3 \\
\hline
\end{tabular}

Table 2: Weight loss values, calculated inhibition efficiencies and corrosion rates of API $5 \mathrm{~L} \mathrm{X-52} \mathrm{steel} \mathrm{corrosion} \mathrm{in} 2 \mathrm{M} \mathrm{HCl}$ in the absence and presence of various concentrations of LEVO

\begin{tabular}{|c|c|c|c|c|c|c|c|}
\hline \multirow{2}{*}{ System } & \multicolumn{5}{|c|}{ Weight loss $(g)$} & \multirow{2}{*}{$\begin{array}{l}I E^{*} \\
(\%)\end{array}$} & \multirow{2}{*}{$\begin{array}{c}\text { Corrosion } \\
\text { rate }^{*}\left(\text { mmy }^{-1}\right)\end{array}$} \\
\hline & 5 days & 10 days & 15 days & 20 days & 25 days & & \\
\hline $2 \mathrm{M} \mathrm{HCl}$ & 1.317 & 2.864 & 4.181 & 5.698 & 6.430 & & 19.86 \\
\hline $2 \mathrm{M} \mathrm{HCl}+50 \mathrm{ppm}$ & 1.080 & 2.160 & 2.200 & 2.300 & 2.400 & 62.7 & 7.41 \\
\hline $2 \mathrm{M} \mathrm{HCl}+200 \mathrm{ppm}$ & 0.720 & 1.116 & 1.504 & 0.741 & 1.346 & 79.1 & 4.16 \\
\hline $2 \mathrm{M} \mathrm{HCl}+500 \mathrm{ppm}$ & 0.651 & 0.723 & 1.044 & 0.468 & 0.360 & 94.4 & 1.11 \\
\hline
\end{tabular}

*Values obtained after 25 days immersion

the electric double layer indicative of the adsorption of the inhibitor molecules at the metal-solution interface. The adsorption of LEVO molecules decreases the electrical capacity of the double layer due to the displacement of water molecules and other ions originally adsorbed on the surface. A protective layer of LEVO molecules is thus formed on the metal surface resulting in a decrease in $Q_{d l}$ and an increase in the charge-transfer resistance. In the absence of the LEVO molecules, chloride ions of the electrolyte adsorb onto the metal surface. Although the addition of inhibitor gradually leads to the displacement of $\mathrm{Cl}^{-}$ions, their presence at relatively low inhibitor concentration may induce a capacitive adsorption region in close proximity to the metal surface which behaves similar to the double layer giving rise to the $R_{a}$ and $Q_{a}$ component in the equivalent circuit. The presence of chloride and sulphate ions have been reported to induce adsorption to the electrochemical process taking place at the metal-solution interface [11]. Furthermore, $\mathrm{Cl}^{-}$and $\mathrm{SO}_{4}{ }^{2-}$ ions play a role in the adsorption of protonated inhibitor molecules by specifically adsorbing to the metal surface thus creating a negative charge towards the solution [12]. It could be argued that at relatively higher inhibitor concentration, most if not all $\mathrm{Cl}^{-}$ions will be displaced resulting in an increased $Q_{a}$ as recorded at $500 \mathrm{ppm}$ of inhibitor concentration. The depressed semicircles at high frequency is typically related with the relaxation of the double layer capacitor and the diameters of the semicircles is often regarded as the charge-transfer resistance, hence $R_{c t}=$ $R_{p}$ [13], where $R_{p}$ is the polarization resistance. Thus, the inhibition efficiency, IE of LEVO for the steel electrode is calculated from the charge-transfer resistance using the expression;

$$
I E(\%)=\frac{R_{p}-R_{p}^{\rho}}{R_{p}} \times 100
$$

where $R_{\mathrm{p}}^{0}$ and $R_{\mathrm{p}}$ are the polarization resistances for the uninhibited and inhibited solutions respectively. The $I E$ values increase with increase in inhibitor concentration with a maximum of $91.3 \%$ at $500 \mathrm{ppm}$ inhibitor concentration in 2 $\mathrm{M} \mathrm{HCl}$.

\subsection{Gravimetric Measurements}

Investigation of corrosion of API 5L X-52 steel in $2 \mathrm{M} \mathrm{HCl}$ solution in the absence and presence of different concentration of LEVO as corrosion inhibitor at room temperature $(303 \mathrm{~K})$ was also studied by gravimetric technique. The results illustrated in Table 2 and Figure 4, reveal that weight loss decreases with increase in inhibitor concentration for any specific time of immersion.

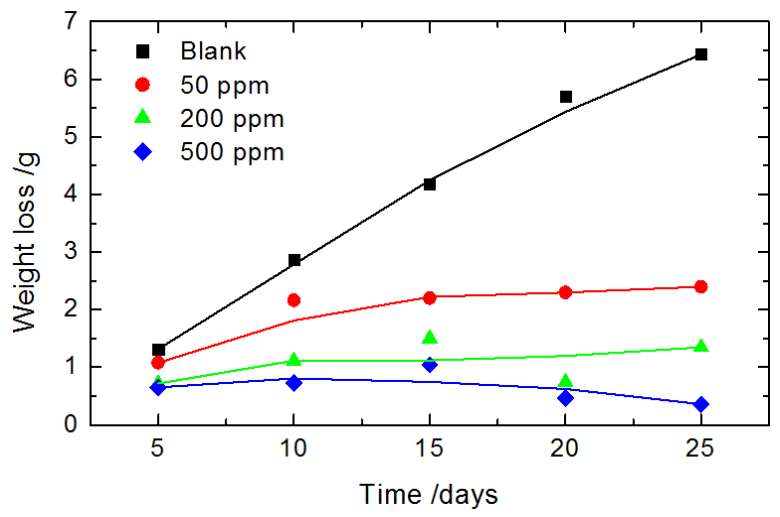

Figure 4: Variation of weight loss with time for the corrosion of API 5L X-52 steel in $2 \mathrm{M} \mathrm{HCl}$ containing various concentrations of $\mathrm{LEVO}$

The weight loss measured at 50 and 200 ppm inhibitor concentration showed a steady increase with time remaining fairly stable for immersions longer than 15 days whereas, the weight loss recorded at $500 \mathrm{ppm}$ showed a slight increase with time and subsequently, a marginal reduction for immersion longer than 15 days. The inhibition efficiency was seen to increase with increase in the concentration of LEVO in the electrolyte (Figure 5). The plot equally shows a decrease in corrosion rate with increasing LEVO concentration. The IE calculated from WL and EIS measurements were 94.4 and $91.3 \%$ respectively at a concentration of $500 \mathrm{ppm}$ of LEVO. The reduction in the dissolution of the carbon steel in the acid- inhibitor solution was attributed to the adsorption of the tested molecules of the 


\section{International Journal of Science and Research (IJSR) \\ ISSN (Online): 2319-7064}

Index Copernicus Value (2015): 78.96 Impact Factor (2015): 6.391

steel surface and their ability to reduce the attack of the aggressive ions of the electrolyte system.

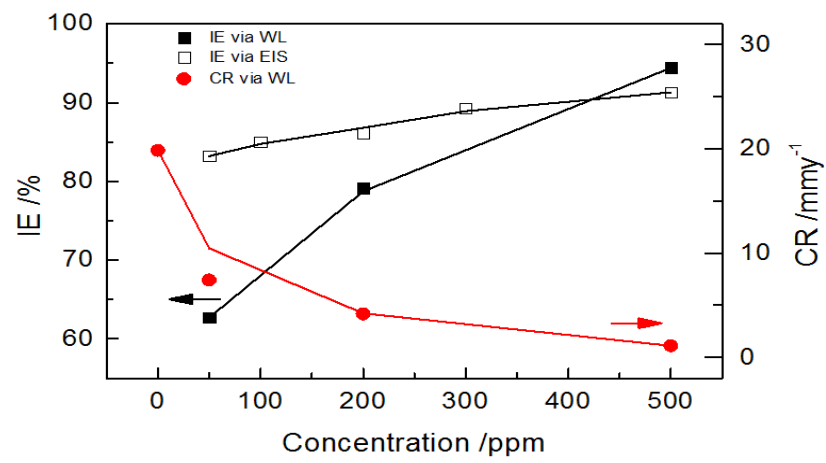

Figure 5: Variation of inhibition efficiency and corrosion rate with inhibitor concentration based on WL and EIS data

\subsection{Kinetic consideration}

Chemical kinetics is introduced in order to assess the stability of the inhibitive behaviour of the inhibitor on time scale and weight loss. The data obtained from weight loss measurements were fitted to the equations of different orders of reaction. The results revealed that data from the corrosion reaction of API 5L X-52 steel in in $2 \mathrm{M} \mathrm{HCl}$ containing various concentrations of LEVO fitted a first order reaction equation (Figure 6). This implies that the rate of corrosion of API 5L X-52 steel in uninhibited and inhibited $2 \mathrm{M} \mathrm{HCl}$ solution is related to the weight of API 5L X-52 steel based on equation 5 [14];

$$
\begin{aligned}
& \ln \frac{W_{f}}{W_{i}}=-K t \\
& t_{1 / 2}=\frac{0.693}{K}
\end{aligned}
$$

The values of rate constant $K$ obtained from the slope of the plot in Figure 6 and the half-life are listed in Table 3. The rate constant decreased and the half-life increased as the concentration of inhibitor increased. Increasing half-life implies that the corrosion rate decreases [2], [15], suggesting that the metal is protected in the presence of LEVO.

\subsection{Adsorption Isotherm}

Majority of inhibitors prevent metal dissolution by adsorption process. The IE of LEVO studied by EIS and gravimetric methods suggests that the surface coverage $(\theta=$ $I E(\%) / 100)$ increased with increasing concentration of the

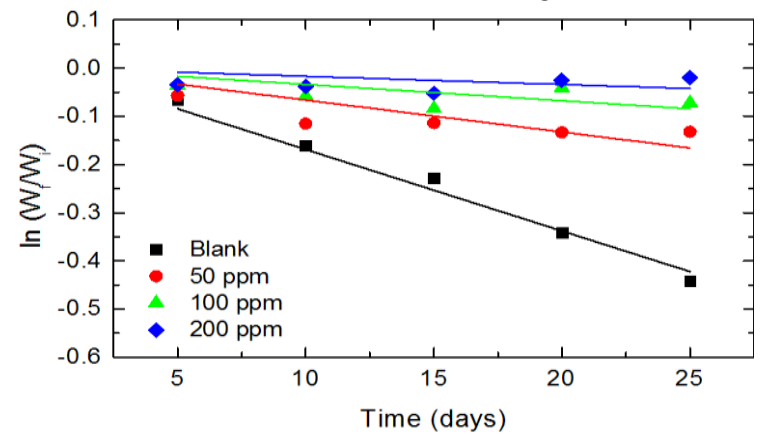

Figure 6: Plot of In $\left(\mathrm{W}_{\mathrm{f}} / \mathrm{W}_{\mathrm{i}}\right)$ against time (days) for API $5 \mathrm{~L}$ $\mathrm{X}-52$ steel in $2 \mathrm{M} \mathrm{HCl}$ solution containing LEVO of different concentrations
Table 3: Values of rate constant and half-life for API 5L X52 steel in uninhibited and inhibited $2 \mathrm{M} \mathrm{HCl}$ solution

\begin{tabular}{|c|c|c|}
\hline System & $\begin{array}{c}\text { Rate constant, } K \\
\left(\text { day }^{-1}\right)\end{array}$ & $\begin{array}{c}\text { Half-life, } t_{1 / 2} \\
(\text { days })\end{array}$ \\
\hline $2 \mathrm{M} \mathrm{HCl}$ & 0.0169 & 41.0 \\
\hline $2 \mathrm{M} \mathrm{HCl}+50 \mathrm{ppm}$ & 0.0066 & 104.5 \\
\hline $2 \mathrm{M} \mathrm{HCl}+200 \mathrm{ppm}$ & 0.0034 & 205.0 \\
\hline $2 \mathrm{M} \mathrm{HCl}+500 \mathrm{ppm}$ & 0.0017 & 407.6 \\
\hline
\end{tabular}

inhibitor. To describe the adsorption behaviour of LEVO, a number of adsorption isotherms have been tested and the Langmuir kinetic model fits the experimental data well. The Langmuir isotherm is given by equation 7;

$$
\frac{c}{\theta}=\frac{1}{K_{\mathrm{ads}}}+C
$$

where $\theta$ is the degree of surface coverage, $C$ is the concentration of the inhibitors and $K_{\text {ads }}$ is the equilibrium constant of the adsorption process. The Langmuir isotherm assumes the adsorption of organic molecules as a monolayer over the metallic surface without any interaction with other molecules adsorbed [16]. The Langmuir isotherm plot shown in Figure 7 applies both gravimetric and EIS data and the equilibrium constant of adsorption $K_{\text {ads }}$ is obtained from the intercept. It is related to the free energy of adsorption $\Delta G_{\text {ads }}$ as;

$$
\Delta G_{\mathrm{ads}}=-2.303 R T \log \left(55.5 K_{\mathrm{ads}}\right)
$$

where $R$ is the universal gas constant, $T$ the absolute temperature and the molar concentration of water in solution is given by the value 55.5. The values for $K_{\text {ads }}$ and $\Delta G_{\text {ads }}$ are provided in Table 4 . The free energy of adsorption calculated from gravimetric and EIS data are -0.99 and $-1.66 \mathrm{~kJ} \mathrm{~mol}^{-1}$ respectively. These values are at the interval of physical adsorption [17]. The negative sign of $\Delta G_{\text {ads }}$ indicates that the adsorption process of levofloxacin over API 5L X-52 steel occurs spontaneously. Recent report [18] confirm active centers for adsorption of the compound levofloxacin to be via the aromatic $\pi$ electrons at specific bond sites in the vicinity of the heteroatoms.

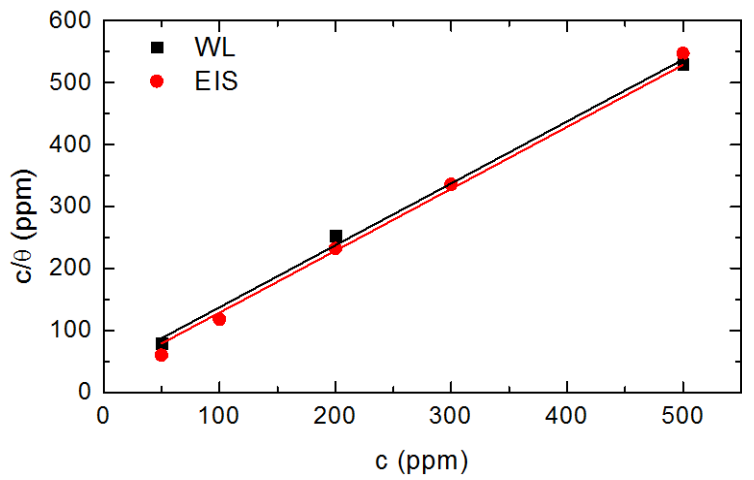

Figure 7: Langmuir adsorption isotherm plot for the adsorption of LEVO on the API 5L X-52 steel in $2 \mathrm{M} \mathrm{HCl}$ solution 


\section{International Journal of Science and Research (IJSR) \\ ISSN (Online): 2319-7064}

Index Copernicus Value (2015): 78.96 | Impact Factor (2015): 6.391

Table 4: Adsorption parameters obtained from Langmuir isotherm for the adsorption of LEVO on API 5L X-52 steel in $2 \mathrm{M} \mathrm{HCl}$ solution at $303 \mathrm{~K}$

\begin{tabular}{|c|c|c|c|}
\hline Method & $\begin{array}{c}\text { Equilibriu } \\
\text { m constant, } \\
K_{\text {ads }}\end{array}$ & $\begin{array}{c}\Delta G_{\text {ads }} \\
\left(\mathrm{kJmol}^{-1}\right)\end{array}$ & $\begin{array}{c}\text { Coefficient of } \\
\text { determination } \\
, R^{2}\end{array}$ \\
\hline WL & $2.7 \times 10^{-2}$ & -0.99 & 0.997 \\
\hline EIS & $3.5 \times 10^{-2}$ & -1.66 & 0.994 \\
\hline
\end{tabular}

\section{Conclusion}

1) Levofloxacin extensively increased the resistance of API $5 \mathrm{~L}$ X-52 steel against corrosion in $2 \mathrm{M} \mathrm{HCl}$ solution and therefore can be employed as eco-friendly, cost effective and commercially available corrosion inhibitor for steel.

2) Inhibition efficiency increases with increase in inhibitor concentration reaching above $90 \%$ at the highest concentration studied.

3) Adsorption of the inhibitor followed Langmuir adsorption isotherm.

4) The kinetics of the corrosion inhibition process is described as being jointly charge-transfer and adsorptioncontrolled following a first order reaction process.

\section{Acknowledgment}

M.E. Ikpi is grateful to the China-Africa Science and Technology Partnership Program (CASTEP) for the 2012 Award for Equipment Donation Support from which the experimental analysis of this research was made possible.

\section{References}

[1] L. Garverick (Ed.), Corrosion in the petrochemical industry, ASM International, Ohio, 1994.

[2] E.M. Attia, "Expired Farcolin drugs as corrosion inhibitor for carbon steel in $1 \mathrm{M} \mathrm{HCl}$ solution," Journal of Basic and Applied Chemistry, V (1), pp. 1-15, 2015.

[3] R.S. Abdel-Hameed, E.A. Ismail, A.H. Abu-Nawwas, H.I. Abu-Nawwas, "Expired voltaren drugs as corrosion inhibitor for Aluminum in hydrochloric acid," International Journal of Electrochemical Science, X, pp. 2098-2109, 2015.

[4] M.S. Morad, "Inhibition of iron corrosion in acid solutions by Cefatrexyl: behaviour near and at the corrosion potential," Corrosion Science, L (2), pp. 436448, 2008.

[5] S. Karthikeyan, P.A. Jeeva, K. Raja, "Docloxacillin: An effective retarder for mild steel dissolution in acid medium," International Journal of Chemical Technology Research, VIII (3), pp. 1391-1395, 2015.

[6] I. Naqvi, A.R. Saleemi, S. Naveed, "Cefixime: A drug as efficient corrosion inhibitor for mild steel in acidic media. Electrochemical thermodynamic studies," International Journal of Electrochemical Science, VI pp. 146-161, 2011.

[7] N.O. Eddy, S.A. Odoemelam, E.C. Ogoko, B.I. Ita, "Inhibition of the corrosion of Zinc in 0.01-0.04 M $\mathrm{H}_{2} \mathrm{SO}_{4}$ by Erythromycin," Portugaliae Electrochemica Acta., XXVIII (1), pp. 15-26, 2010.
[8] I.A. Akpan, N.O. Offiong, "Electrochemical investigation of the inhibitory action of Ciprofloxacin drugs on the acid corrosion of mild steel," Chemical and Process Engineering Research, XXVI, pp. 20-23, 2014.

[9] K.F. Khaled, M.M. Al-Qahtani, "The inhibitive effect of some tetrazole derivatives towards $\mathrm{Al}$ corrosion in acid solution: Chemical, electrochemical and theoretical studies," Materials Chemistry and Physics, CXIII, pp. 150-158, 2009.

[10] R. Macdonald, D.R. Franceschetti, in: J.R. Macdonald (Ed.), Impedance Spectroscopy, Wiley, New York, 1987.

[11] I.M. Gadala, A. Alfantazi, "Electrochemical behaviour of API-X100 pipeline steel in NS4, near-neutral, and mildly alkaline $\mathrm{pH}$ simulated soil solutions", Corrosion Science, LXXXII, pp. 45-57, 2014.

[12] M.E. Ikpi, I.I. Udoh, P.C. Okafor, U.J. Ekpe, E.E. Ebenso, "Corrosion inhibition and Adsorption behaviour of extracts from Piper guineesis on mild steel corrosion in acid media," International Journal Electrochemical Science, VII, pp. 12193-12206, 2012.

[13] H. Ma, S. Chen, L. Niu, S. Zhao, S. Li, D. Li, "Inhibition of copper corrosion by several Schiff bases in aerated halide solutions," Journal of Applied Electrochemistry, XXXII(1), pp. 65-72, 2002.

[14] P.O. Ameh, P. Ukoha, P. Ejikeme, N.O. Eddy, "Thermodynamic Chemical and Electrochemical investigation of 4-hydobenzoic acid as corrosion inhibitor for mild steel corrosion in hydrochloric acid solution," Industrial Chemistry, XX (2), pp. 2469-9764, 2016.

[15] J. Bhawsar, P.K. Jain, P. Jain, "Experimental and Computational Studies of Nicotiana tabacum leaves extract as green corrosion inhibitor for mild steel in acidic medium," Alexandria Engineering Journal, LIV (3), pp. 769-775, 2015.

[16] A.I. Onuchukwu, Chemistry of Surface and Colloid, Ambix Printers, Lagos, 2006.

[17] E. Khamis, F. Bellucci, R.M. Latanision, E.S.H. ElAshry, "Acid Corrosion Inhibition of Nickel by 2(Triphenosphoranylidene Succinic Anhydride," Corrosion, XLVII, pp. 677-686, 1991.

[18] M.E. Ikpi, F.E. Abeng, "Theoretical study on the structural effect of Benzoxazin derivative as corrosion inhibitor for carbon steel in acid media," Submitted to Chemical Science Transactions, 2017.

\section{Author Profile}



Magdalene Ikpi obtained B.Sc. (Chemistry) and M.Sc. (Physical Chemistry) degrees from the University of Calabar, Nigeria in 1996 and 2002 respectively. She acquired a Ph.D. degree from the University of Cambridge, United Kingdom in 2006 with specialty in Lowdimensional Quantum dot structures. She has been involved in research and teaching for over 19 years at the Department of Pure and Applied Chemistry, University of Calabar, Nigeria. Her current research interest is in corrosion inhibition studies and structural integrity of buried oil/gas transmission pipelines. 


\section{International Journal of Science and Research (IJSR) \\ ISSN (Online): 2319-7064}

Index Copernicus Value (2015): 78.96 | Impact Factor (2015): 6.391

Fidelis Abeng holds a B.Sc. degree in Chemistry (2006), M.Sc. (2012) and Ph.D. (2016) degrees in

Physical Chemistry from the University of Calabar,

Nigeria. $\mathrm{He}$ is currently working as a Part-time Lecturer with the Cross River University of Technology, Obubra Campus. His research interest is in corrosion studies and quantum chemical studies of corrosion inhibition processes.

Volume 6 Issue 6, June 2017 www.ijsr.net 